\title{
Základní společensko-politické reálie současné Bosny a Hercegoviny a jejich translatologické reflexe v češtině
}

\section{Basic Socio-Political Facts of Contemporary Bosnia and Herzegovina and their Translatological Reflection in Czech}

\author{
Pavel Krejčí \\ (Brno, Česko)
}

\begin{abstract}
Abstrakt:
Článek se zabývá staršími a aktuálními významy srbochorvatských onym vyjadřujících základní společensko-politické reálie současné Bosny a Hercegoviny (Bosanac, Bošnjak, Musliman, Srpska), významy adjektiv bosanski a bošnjački a jejich překladovými ekvivalenty v češtině. Dochází $\mathrm{k}$ závěru, že české ekvivalenty Bosňan a Bosňák navzdory údajům ve starších slovnících češtiny nelze $\mathrm{v}$ současnosti chápat jako synonyma, a to samé platí i o adjektivech bosenský a bosňácký, českých ekvivalentech př́slušných srbochorvatských adjektiv. Při užívání pojmů spjatých se složitou společensko-politickou situací v Bosně a Hercegovině v cizích jazycích je třeba postupovat velice obezřetně.
\end{abstract}

\section{Klíčová slova:}

Bosna a Hercegovina; Srpska; Bosňan; Bosňák; bosenský; bosňácký

\section{Abstract:}

The article deals with the older and current meanings of Serbo-Croatian onymes expressing the basic socio-political facts of contemporary Bosnia and Herzegovina (Bosanac, Bošnjak, Musliman, Srpska), the meanings of adjectives bosanski and bošnjački and their translation equivalents in Czech. It concludes that, despite the data in older Czech dictionaries, Czech equivalents Bosňan „Bosnian“ and Bosňák „Bosniak“ cannot 
currently be understood as synonyms, and the same is true of adjectives bosensk $y$ „Bosnian“ and bosňácký „Bosniak“, Czech equivalents of the respective Serbo-Croatian adjectives. The use of terms related to the difficult socio-political situation in Bosnia and Herzegovina in foreign languages needs to be very cautious.

\section{Key words:}

Bosnia and Herzegovina; Srpska; Bosnian; Bosniak

\section{Historický úvod - muslimský prvek v Bosně a Hercegovinĕ}

Rozpad jugoslávské federace (1991-1992) neznamenal jen vznik nových státních útvarů na mapě Evropy, ale také vytvoření nové etnické situace (především v důsledku války v Chorvatsku, Bosně a Hercegovině a na Kosovu). Součástí této nové situace byla i změna národního jména jugoslávských, především však bosensko-hercegovských slovanských muslimů (připomínáme, že z historických důvodů se slovanský muslimský živel v bývalé Jugoslávii nacházel a dodnes nachází především v Bosně a Hercegovině a v Sandžaku, což je region na pomezí Srbska a Černé Hory).

Muslimský živel v Bosně a Hercegovině (BaH) v minulosti používal jména, která byla přirozeně odvozena od pojmenování území, kde se ten živel vyskytoval. Tento vztah bychom mohli schematizovat jako Bosna $\rightarrow$ Bošnjanin, Bošnjak. Výraz Bosanac je novější a používalo se ještě čtvrté jméno - Bosanlija. Dokládá to Srpski rječnik Vuka S. Karadžiće (1818, 2. vyd. 1852), v němž (v obou vydáních) jsou výrazy Bošnjak a Bošnjanin chápány jako primární:

Српски рјечник (SR 1966 [1818], resp. 1852):

Бошњак - der Bosnier, Bosnus homo

Бошњанин - der Bosnier, Bosnus (s. 43, resp. 38)

Босанац - vide Бошњак

Босанлија - vide Бошњак (s. 42, resp. 38)

V době národně-integračních procesů a formování moderních jihoslovanských národů došlo $\mathrm{k}$ postupnému ztotožňování bosensko-hercegovských katolíků s chorvatskou národní myšlenkou a tamních pravoslavných zase se srbskou identitou. Od muslimského živlu se očekávalo, že časem přijme bud’ chorvatskou, nebo srbskou identitu, nakonec se však bosenští a hercegovští muslimové vydali vlastní cestou, která byla do určité míry reakcí jednak na srbsko-chorvatské „přetahováni“ o muslimy a jednak i na to, že je-li odlišná historická zkušenost a odlišná víra dostatečným 
důvodem pro nejednotu jinak jazykově prakticky identických Srbů a Chorvatů, proč by potom bosensko-hercegovští muslimové s taktéž odlišnými historickými zkušenostmi nemohli jít rovněž vlastní cestou? (srov. k tomu článek Josipa Ljubiće z roku 1895 Spor između Srba i Hrvata). ${ }^{1}$ Ta vlastní cesta byla pojmenována výrazem bošnjaštvo a u bosensko-hercegovských muslimů podporovala myšlenku budování vlastní pospolitosti pojmenované etnonymem Bošnjaci odvozeným právě od území, které bylo jejich historickou domovinou. Čili zobecněno: „mi nismo Hrvati, niti smo Srbi, mi smo Bošnjaci“. Jestliže idea bošnjaštva (bosňáctví) byla zaměřená především dovnitř samotné muslimské komunity a vykazovala už i „prvky vědomí etnického a politického“, ${ }^{2}$ pak idea tzv. bosanstva (bosenství) „stavěla především na vědomí zemském - regionálním“. 3 Čili zobecněno: „muslimani, pravoslavci, rimokatolici nije bitno, važno je što smo svi Bosanci“. Rozkvět obou myšlenkových směrů nastal v době, kdy Bosnu a Hercegovinu spravoval c. a k. ministr financí Benjamin Kállay (1882-1903). ${ }^{4}$ Ten podporoval především bosenský zemský patriotismus, nebot ho vnímal jako hráz proti kroatizaci, resp. srbizaci obyvatelstva Bosny a Hercegoviny. Označení (bosanski) muslimani se začalo hojněji používat až počátkem 2o. století jako náhrada za do té doby užívané pojmenování mohamedani, které bylo samotnými muslimy v BaH kritizováno jako „evropská vymyšlenina“, kterou ovšem sami muslimové nepoužívají. ${ }^{5}$ Rozšíření tohoto de facto religiozního označení mělo za následek postupnou marginalizaci etnonyma Bošnjaci, které nezískalo patřičnou „životní sílu“ mj. i proto, že mezi muslimy v BaH nedošlo k finalizaci jejich národně-integračního procesu, který by toto etnonymum $\mathrm{v}$ jugoslávském, a poté i mezinárodním diskurzu logicky definitivně ukotvil.

1 HLADKÝ, L.: Bosna a Hercegovina. Historie neštastné země. Brno: Doplněk, 1996, s. 49-50.

2 Tamtéž, s. 48.

3 Tamtéž.

4 Poté, co Rakousko-Uhersko získalo na berlínském kongresu roku 1878 mandát k obsazení a správě Bosny a Hercegoviny, tento nový útvar v rámci monarchie nebyl začleněn ani do rakouské, ani do uherské části, ale stal se zvláštní teritoriální jednotkou, kterou spravoval c. a k. ministr financí. K anexi BaH ze strany habsburské monarchie došlo v roce 1908, od konce roku 1918 až do jara 1992 byla BaH součástí jugoslávského státu (s výjimkou let 1941 až 1945, kdy byla v rámci ustašovského Nezávislého státu Chorvatsko). V rámci první, královské Jugoslávie netvořila $\mathrm{BaH}$ žádnou administrativní jednotku, teprve v komunisty ovládané federativní Jugoslávii po roce 1945 získala status jedné z šesti svazových republik. Po vyhlášení nezávislosti a následné krvavé občanské válce (1992-1995) získala Bosna a Hercegovina současnou podobu státu složeného ze dvou tzv. entit (Federace Bosny a Hercegoviny a Republika srbská) a Brčko Distriktu - okresu na severovýchodě Bosny se specifickým statutem.

5 Tamtéž, s. 50. 


\section{Onyma Bosanac, Bošnjak, Musliman před rokem 1990}

Označení Muslimani (tedy s velkým iniciálním písmenem) se objevuje už v době druhé světové války - nejstarší záznam, který se nám podařilo zjistit, je Rezoluce o založení AVNOf z listopadu 1942. ${ }^{6}$ Muslimská národnost (Muslimové) ${ }^{7}$ byla v Jugoslávii poprvé oficiálně zavedena pro sčítání obyvatelstva v roce $1961 .^{8}$

Současně se v dobách federativní Jugoslávie rozšíríl i výraz Bosanci. O obsahu etnonym Bosanac, Bošnjak, Bošnjanin a Musliman podávají informace slovníky, jež byly v té době vydány:

Речник савременог српског књижевног језика с језичким саветником (RSSKJ 2000 [1966]):

Босанац - становник Босне; Човек родом из Босне. вар. Бошњак, Бошњанин (s. 55)

Бошњак, Бошњанин - в. Босанац (s. 56)

Речник српскохрватског књижевног и народног језика (RSHKNJ 1962, 1988):

Босанац - 1. становник Босне; онај који је пореклом из Босне. исп. Босанлија, Бошњак (1), Бошњан, Бошњанац, Бошњанин (s. 73)

Бошњак - 1. в. Босанац (s. 85)

Бошњанин - в. Босанац (s. 86)

муслиман - 2. (Муслиман) припадник југословенског народа ове конфесије, насталог углавном од исламизираног становништва у српскохрватској језичкој области, који највећим делом живи у СР Босни и Херцеговини (s.313)

Речник српскохрватскога књижевног језика (RSHKJ 1967, 1969):

Босанац - човек из Босне (s. 253)

Бошњак - а. Босанац; б. заст. муслиман из Босне (s. 256)

Бошњанин - заст. Босанац (s. 256)

6 KREJČÍ, P.: Eight Fragments from the World of Serbian, Croatian, Bosnian and Montenegrin Languages. Selected South Slavonic Studies 1. Brno: Masaryk University, 2018, s. 92. „Narod je krvavo platio u takvim krajevima svoju naivnu veru u sporazum četnika sa ustašama i okupatorima, i taj se sporazum na delu pokazao kao sporazum za masovno ubijanje Hrvata i Muslimana od strane četnika, a Srba od strane ustaša, no na mnogim mestima pokolje vrše svi ti zlikovci zajedno i nad Srbima i nad Hrvatima i nad Muslimanima" (Rezolucija o osnivanju AVNOF, 1942, s. 4).

7 Čeština psaní s velkým počátečním písmenem jednoduše převzala z jugoslávské normy. SSJČ ani SSČ však tvar Muslim nezaznamenává, na rozdíl od Slovníku cizích slov, který jej definuje slovy „př́slušník národnostní skupiny v Bosně“ (KLIMEŠ, L.: Slovník cizích slov. 5., přepracované a doplněné vydání. Praha: SPN, 1994, s. 495).

8 MRDJEN, S.: Narodnost u popisima. Promjenljiva i nestalna kategorija. In: Stanovništvo, 1-4, 2002, s. 8 o. 
муслиман - 2. (Муслиман) припадник народа ове конфесије који највећим делом живи у СР Босни и Херцеговини (s. 466)

Rječnik hrvatskosrpskoga književnog jezika (RHSKJ 1967):

Bosanac: čovjek iz Bosne (s. 241)

Bošnjak: a. Bosanac; b. zast. musliman iz Bosne (s. 242)

Bošnjanin: zast. Bosanac (s. 242)

Z údajů je patrné, že výraz Bosanac je pokaždé jednoznačně chápán jako obyvatelské jméno, zatímco Bošnjanin je bud's odkazem na Bosanac nebo s prŕíznakem zastaralý. Bošnjak je rovněž opatřen odkazem na Bosanac, RSHKJ, resp. RHSKJ ovšem uvádějí i význam „muslim z Bosny“ s př́íznakem zastarale (autoři slovníků samosebou nemohli tušit, že o čtvrtstoletí později bude tento význam opět navýsost aktuální). ${ }^{9}$

Výraz Musliman chybí u Moskovljeviće (RSSKJ) a v RHSKJ, nebot ten končí písmenem K. Oba vícesvazkové slovníky srbochorvatštiny (RSHKNJ a RSHKJ), připravované ovšem v Srbsku, mají toto specifické etnonymum shodně jako druhý význam výrazu musliman „muslim“.

\section{Onyma Bosanac, Bošnjak, Musliman po roce 1990}

Převratné společensko-politické události první poloviny 9o. let mj. přinesly změnu v národní sebeidentifikaci bosensko-hercegovských muslimů - na Bosňáckém sněmu v Sarajevu v roce 1993 se rozhodli opustit pojmenování Musliman rozšířené během vlády jugoslávských komunistů a vrátit se ke starému označení Bošnjak jako tradičnímu a svou formou přirozenému etnickému pojmenování, které by je v rámci pestré etnické struktury Bosny a Hercegoviny vymezilo vůči tamním Srbům a Chorvatům. Tato nová skutečnost se projevila i ve výkladových slovnících vydaných po roce 1990:

9 Identický výklad sledovaných hesel v RSHKJ a RHSKJ odpovídá závazku, že oba slovníky, které byly vydány oběma národními maticemi (srbskou v Novém Sadu a chorvatskou v Záhřebu), budou obsahově identické a lišit se budou pouze v tom, že slovník Matice chorvatské bude psán latinkou a ijekavskou variantou, kdežto slovník Matice srbské cyrilicí a ekavskou variantou srbochorvatštiny. Oba slovníky také na titulní straně uvádějí jména obou matic i sestavy obou autorských kolektivů. Liší se ovšem ve svém osudu: zatímco Matice srbská dokončila v období 1967 až 1976 všech šest svazků, Matice chorvatská vydala v roce 1967 jen první dva svazky (A-F a G-K) a poté - v souvislosti se vzedmutou vlnou chorvatského nacionalismu projevující se mj. kritikou nedodržování tzv. novosadské dohody o srbochorvatštině z roku 1954 (známá Deklaracija o nazivu i položaju hrvatskog književnog jezika [1967]) a vrcholící tzv. chorvatským jarem (1971) - na další díly rezignovala. Rječnik hrvatskosrpskoga književnog jezika tedy zůstal jen torzem. 
Školski rječnik bosanskog jezika (ŠRBJ 1999):

Bosanac - čovjek iz Bosne (s. 125)

Bošnjak - pripadnik bošnjačkog naroda; Musliman (etnički), Musliman-Bošnjak, Bošnjanin (hist.) (s. 126)

Bošnjanin - Bošnjak, Bosanac (s. 126)

bosanski musliman - Bošnjak, musliman (s. 125)

Rječnik bosanskog jezika (RBJ 2007):

Bosanac - stanovnik Bosne (s. 46)

Bošnjak - pripadnik bošnjačke nacije (s. 47)

Bošnjanin - naziv za narod koji je živio u srednjovjekovnoj Bosni prije dolaska Turaka (s. 47)

Rječnik hrvatskoga jezika (RHJ 200o):

Bosanac - etn. 1. čeljade koje je rodom iz Bosne; 2. osoba koja živi u Bosni (s. 93)

Bošnjak - etn. 1. čovjek rodom iz Bosne; Bosanac; 2. stanovnik Bosne; 3. pol. bosansko-hercegovački musliman (s. 94)

Veliki rječnik hrvatskoga jezika (VRHJ 2003):

Bosanac - 1. razg. stanovnik Bosne; Bošnjanin 2. v. Bošnjak (s. 106)

Bošnjak - 1. stanovnik i građanin Bosne kao nosilac uređenja Bosne kao zemlje i države u različitim političkim i kulturno-prosvjetnim programima; Bosanac 2. pripadnik nacije kojoj je Bosna domovina (Musliman) (s. 106)

Bošnjanin - arh. knjiš. v. Bosanac (1) (s. 106)

musliman - 2. (Musliman) pov. neol. pripadnik muslimanske nacionalnosti u BiH; Bošnjak (s. 789)

Речник српскога језика (RSJ 2007):

Босанац - 1. становник Босне; човек пореклом из Босне (s. 104)

Бошњак - а. муслиман из Босне; б. припадник јужнословенског народа исламске вероисповести, претежно насељеног у Босни (s. 105)

Nové slovníky se v zásadě shodují u definice obyvatelského jména Bosanac, pouze VRHJ jej ve druhém významu ztotožňuje s prvním významem slova Bošnjak, které je tu chápáno právě jako obyvatelské jméno („obyvatel a občan Bosny“). Tento smysl uvádí ještě RHJ (první a druhý význam). RSJ toto jméno chápe bud jako neetnické označení bosenského muslima (srov. též bosanski musliman v ŠRBJ), anebo jako etnonymum. A tuto etnonymickou funkci uvádějí i všechny další slovníky (ŠRBJ, RBJ, RHJ - třetí význam ${ }^{10}$ a VRHJ - druhý význam). Výraz Bošnjanin RSJ ani RHJ neuvádí, podle

10 Ovšem bez jemné významové nuance, kterou zachytil RSJ. 
VRHJ nese příznak archaičnosti a knižnosti, je chápán jako synonymum k Bosanac (VRHJ), resp. k Bošnjak, Bosanac (ŠRBJ). Autoři RBJ jej vnímají jako historismus. Výraz Musliman jako specifické etnonymum ztratil politickou podporu poměrně záhy po rozpadu SFR Jugoslávie a vzniku samostatné Bosny a Hercegoviny a byl poměrně úspěšně nahrazen etnonymem Bošnjak. Je tedy pochopitelné, že jej prakticky všechny současné postsrbochorvatské slovníky ignorují - s výjimkou Anićova VRHJ, který jej definuje velice podobně jako starší RSHKJ a RSHKNJ, jen s příznakem „historismus“ a „neologismus“ (pov. neol.) a navíc jej doplňuje aktuálním synonymem Bošnjak.

Z rešerše postjugoslávských slovníků je patrné, že revitalizace jména Bošnjak a aktualizace jeho smyslu byla zaznamenána a akceptována ve všech postsrbochorvatských jazycích, Bosanac si ponechává svoji funkci obyvatelského jména. Obě jména mají tedy svůj vlastní obsah a nelze je $\mathrm{v}$ žádném případě zaměňovat nebo vnímat jako synonyma.

\section{Adjektiva bosanski vs. bošnjački}

Zabýváme-li se jmény Bosanac a Bošnjak a jejich obsahem, je v tuto chvíli jistě na místě zmínit i př́́davná jména bosanski a bošnjački, nebot’ s nimi (a též s toponymem Bosna) úzce souvisejí a je nutné vědět, v jakém kontextu lze užít prvního a v jakém druhého adjektiva. Nahlédněme opět do slovníků:

\section{BOSANSКI/БОСАНСКИ:}

који се односи на Босну; који припада Босни; који је пореклом из Босне (RSHKNJ 1962: 73)

који се односи на Босну и Босанце (RSHKJ 1967: 253)

koji se odnosi na Bosnu i Bosance (RHSKJ 1967: 241)

koji se odnosi na Bosnu i Bosance (RHJ 2000: 93)

koji se odnosi na Bosnu (kao ime zemlje) i Bosance (VRHJ 2003: 106)

који се односи на Босну и Босанце (RSJ 2007: 104)

koji se odnosi na Bosnu i Bosance (RBJ 2007: 46)

\section{BОŠNҰАС̆КІ/БОШЊА ЧКИ:}

који се односи на Бошњака, Босну (RSHKNJ 1962: 86)

који се односи на Бошњаке; босански (RSHKJ 1967: 256)

koji se odnosi na Bošnjake; bosanski (RHSKJ 1967: 242)

koji se odnosi na Bošnjake (RHJ 2000: 94)

koji se odnosi na Bošnjake (VRHJ 2003: 106)

који се односи на Бошњаке (RSJ 2007: 105)

koji se odnosi na Bošnjake (RBJ 2007: 47) 
Z rešerše jugoslávských i postjugoslávských slovníků ${ }^{11}$ je patrné, že shoda v pohledu na význam obou adjektiv je prakticky úplná: výraz bosanski je v zásadě vysvětlován jako „vztahující se na Bosnu a její obyvatele, kteří se v originále nazývají Bosanci“, výraz bošnjački je zase vykládán jako „vztahující se k pojmenování Bošnjak“. Drobný rozdíl je patrný v lexikografickém výkladu před rokem 1990 a po něm. Slovníky obou matic toto adjektivum explicitně vnímají jako v podstatě synonymní k bosanski (což př́liš nepřekvapí, srovnáme-li ještě jednou tehdejší výklady jmen Bosanac a Bošnjak), zatímco současné slovníky (oba chorvatské, bosenský i srbský) takový výklad již nepřipouštějí a jejich definiční jednota je úplná.

Situace $\mathrm{v}$ postsrbochorvatském prostoru je tedy poměrně jasná - Bosanac je jméno označující jakéhokoliv obyvatele Bosny (stejně jako jména Hercegovac, Dalmatinac, Slavonac, Vojvođanin apod. označují obyvatele Hercegoviny, Dalmácie, Slavonie, Vojvodiny apod.), je to zemské či regionální označení. Bošnjak je jméno národní (etnonymum), a to národa, jehož charakteristickým rysem bývá islámská víra (ta ovšem není podmínkou), kultura, tradice a ve většině případů i Bosna coby mateřská země (toto se samozřejmě netýká muslimů stejné národnosti ze Srbska nebo Černé Hory). Př́slušníci tohoto národa byli v době komunistické Jugoslávie označováni neobvyklým etnonymem Muslimani.

\section{V. Česká jazyková reflexe výše popsané situace}

Při potřebě vyjádřit ne zcela jednoduchou, ale $\mathrm{v}$ zásadě poměrně jasnou terminologickou situaci popisující společensko-politické reálie Bosny a Hercegoviny v jiném jazyce může dojít k potížím nejrůznějšího charakteru, např::

- cílový jazyk potřebný výraz ve své slovní zásobě vůbec nemá; ${ }^{12}$

- cílový jazyk nemusí disponovat patřičnými ekvivalentními výrazy zohledňujícími jemnější rozdíly z prostředí výchozího jazyka; ${ }^{13}$

- cílový jazyk sice disponuje potenciálně ekvivalentními výrazy, ale ty z různých důvodů použít nelze. ${ }^{14}$

Nahlédneme-li do slovníků českého jazyka, zjistíme, že čeština v zásadě disponuje potřebnými výrazy, kterými může vyjádřit specifické reálie Bosny a Hercegoviny. Slovníky obsahují vlastní jména Bosňan a Bosňák a př́davná jména bosenskýa bosňácký. Jejich popis je následující:

11 Jediné slovníky, které žádné ze zkoumaných adjektiv neuvádějí, jsou RSSKJ a ŠRBJ.

12 V takovém prípadě dochází u toponym k přejímání - př. angl. Wales - čes. Wales, chorv. Wales; chorv. Lika - čes. Lika, angl. Lika.

13 Př.: rus. русский vs. российский - čes. pouze ruský, angl. pouze Russian; srb. Србин, српски vs. Србијанац, србијански - angl. rovněž Serb vs. Serbian, čes. ale pouze Srb, srbský.

14 Př.: srb. Србија vs. Српска - čes. Srbsko vs. ? (Srby? Srbie?), angl. Serbia vs. Srpska. 
Slovník jazyka českého (SJČ 1952 [1934-1937])

Bosna - země; bosňácký: př́íd. k Bosňák, bosňák

Bosňák: obyvatel Bosny, rodák z ní

Bosňan: Bosňák (s. 98)

bosenský - př́d. k Bosna (s. 98)

Př́ruční slovník jazyka českého (PSJČ 2007-2008 [1935-1937])

Bosňan - obyvatel Bosny, Bosňák

Bosňák - obyvatel Bosny, Bosňan

bosenský - adj. k Bosna

bosňácký - adj. lid. a arch. k Bosňák, bosenský

Slovník spisovného jazyka českého (SSJČ 1989 [1960])

Bosna - [...] Bosňan; Bosňák v. t.; bosenský (s. 153)

Bosňák - ob[ecněčesky] obyvatel Bosny; Bosňan; bosňácký (s. 154)

bosenský - v. Bosna (s. 153)

bosňácký - v. Bosňák (s. 153)

Slovník spisovné češtiny pro školu a veřejnost (SSČ 2000 [1978])

Bosna, Bosna a Hercegovina st[át]; Bosňan, bosenský (s. 626)

Problém tedy není v nepřítomnosti hesel, ale v jejich výkladu, což je dáno především zastaralostí českých slovníků - pouze jediný vychází i po roce 1990 (SSČ), ale ten nemá toponyma ani etnonyma jako samostatná hesla, kde by byl prostor pro podrobnější popis významu, nýbrž je nutno nahlédnout do speciálního seznamu zeměpisných jmen, kde je ovšem patřičná informace jen velice stručná a bez popisu. Dozvíme se jen to, že obyvatel Bosny (resp. státu Bosna a Hercegovina) je Bosňan a adjektivum vztahující se $\mathrm{k}$ tomuto území je bosenský. Starší slovníky přirozeně aktuální situaci neodpovídají, Bosňan a Bosñák vnímají jako synonyma, bosenský vykládají jako „vztahující se k Bosně“, bosňácký zas jako „vztahující se k Bosňák“ a v zásadě opět jako synonymní $\mathrm{k}$ bosenský. $\mathrm{Z}$ toho plyne, že chce-li uživatel češtiny vyjádřit správně terminologicky současnou společensko-politickou situaci v BaH, slovníky mu nijak neporadí, ba naopak spíše mu poskytnou nepřesné, neúplné a zavádějící informace.

\section{Společensko-politické reálie současné Bosny a Hercegoviny}

Samotná složitost společensko-politických reálií Bosny a Hercegoviny odražená $\mathrm{v}$ tamním jazyce (ał̉ už ho nazveme jakkoliv) rovněž nepřispívá $\mathrm{k}$ jejich snadnému 
vyjádření v jiném jazyce. Stát nemá oficiální politický název, používá pouze geografické jméno Bosna i Hercegovina..$^{15}$ Jeho dvě entity mají opačný problém.

\section{VI.1 Federacija Bosne i Hercegovine}

Federacija Bosne i Hercegovine je formální jméno, které - budeme-li se držet jazykové podoby - lze vykládat jako federaci dvou zemí (Bosny a Hercegoviny), ${ }^{16}$ anebo také jako oficiální název státu (federace dvou entit vytvořených fakticky podle národnostního klíče). Ani jeden výklad ale není správný, podoba názvu je silně zavádějící. $Z$ toho důvodu se také ihned po jejím vzniku ${ }^{17}$ novináři všemožně snažili její název upřesňovat, a tak používali neoficiální, ale realitu více nebo méně přesněji odrážející opisná pojmenování, nejčastěji muslimsko-chorvatská federace, bosensko-chorvatská federace, okrajově i bosňácko-chorvatská federace. Problematický obsah prvních dvou podob je ale zřejmý (federace Chorvatska s nějakými muslimy? federace Bosny s Chorvatskem?), kdežto třetí varianta už realitu odrážela a odráží mnohem lépe (ovšem za předpokladu správné interpretace adjektiva bosňácký, která zase není možná bez správného pochopení etnonyma Bosňák). Skutečnost je taková, že se jedná o federaci desíti samosprávných kantonů, anebo ji lze také etnicky interpretovat jako federaci v BaH žijících Bosňáků a Chorvatů. Protože však tento politický útvar nemá žádnou historii, nemá ani žádné geografické jméno. Proto se jako zkrácená verze oficiálního názvu nejčastěji užívá podoba Federacija BiH nebo jen Federacija, umožňuje-li to kontext.

\section{VI.2 Republika Srpska}

Druhá entita má oficiální název Република Српска. ${ }^{18}$ Její problém spočíval (a dojisté míry ještě stále spočívá) v tom, že její tvưrci revitalizovali již dávno nepoužívané a archaické jméno pro Srbsko a vetkli je do názvu svého „Srbska“ nacházejícího se v Bosně a Hercegovině. Jméno (choronymum) Српска je skutečně substantivum, ale i v bosenskosrbském prostředí se s ním jeho občané stále ještě poměrně obtížně sžívají, proto vedle samostatného užití tohoto choronyma (např. v názvu letecké společnosti Air Srpska) stále převládá užívání formálního (politického) názvu. Druhá entita tedy

15 V Evropě v tomto aspektu není výjimkou, podobně jsou bez politického názvu (angl. formal, official name) Ukrajina, Rumunsko, Madarsko, Černá Hora, Gruzie a Irsko.

16 Stejně jako např. The United Kingdom of Great Britain and Northern Ireland.

17 Federace BaH byla založena v březnu 1994, sdružily se v ní oblasti BaH ovládané tamními muslimy (Republika Bosna a Hercegovina) a bosensko-hercegovskými Chorvaty (Chorvatská republika Herceg-Bosna).

18 Republika srbská byla založena v lednu 1992, tehdy jako Srbská republika Bosna a Hercegovina. 
své geografické jméno má, ale jeho samostatné užívání není stále dostatečně rozšířené a zažité.

\section{VI.3 Bosanski jezik}

Početně převažujícím národem v BaH byli v dobách Jugoslávie tamní Muslimové, kteří se od roku 1993 oficiálně označují jako Bošnjaci. Jazyk, kterým hovoří, ovšem nazývají adjektivem bosanski, nikoliv bošnjački, jak bychom asi očekávali s ohledem na etnický klíč pro pojmenování jazyků v postsrbochorvatském prostoru („Srbi govore srpski, Hrvati govore hrvatski, Crnogorci govore crnogorski, dakle Bošnjaci govore bošnjački“). Proč tomu tak je, vysvětluje především deklarace nazvaná Povelja o bosanskom jeziku z března 2002. ${ }^{19}$ Jedním z hlavních argumentů je navázání na dlouhou tradici tohoto lingvonyma. Pochopení celé situace jistě nepomáhá ani oficiální prrístup chorvatských a srbských lingvistů, kteří tento jazyk označují jako bošnjački právě s odkazem na výše zmíněný etnický klíč.

\section{VII. Česká jazyková reflexe společensko-politických reálií současné Bosny a Hercegoviny}

\section{VII.1 Bosňan vs. Bosňák}

Pro pojmenování obyvatele Bosny nebo občana Bosny a Hercegoviny bez ohledu na národnost nebo náboženskou př́slušnost je jediným možným obyvatelským jménem slovo Bosňan, které je ekvivalentem orig. Bosanac. Pro pojmenování příslušníka jednoho ze tř́ konstitutivních národů Bosny a Hercegoviny, který se vyznačuje islámským náboženstvím a/nebo tradicí a kulturou, je jediným možným etnonymem slovo Bosňák, které je ekvivalentem orig. Bošnjak. ${ }^{20}$ Někdy se lze v českém prostředí setkat i s výrazem *Bosenec, což je vlastně počeštěný Bosanac. Lze na něj často narazit $\mathrm{v}$ textech laiků nebo méně informovaných novinářủ, kteří jsou s Bosnou a Hercegovinou v kontaktu a výraz Bosanac tam slýchali. Tento naivní prŕstup je

19 Více o ní a vůbec o problematice pojmenování jazyka bosensko-hercegovských muslimů viz KREJČÍ, P.: Lingvonyma v ústavách postjugoslávských státních útvarů (Chorvatsko, Bosna a Hercegovina, Srbsko a Černá Hora). In: BOGOCZOVÁ, I., NEDOMOVÁ, Z. (red.): Area Slavica 2. Slovanské jazyky ve světle termínu. Ostrava: Ostravská univerzita, 2018, s. 30-35 nebo KREJČÍ, P.: Eight Fragments from the World of Serbian, Croatian, Bosnian and Montenegrin Languages. Selected South Slavonic Studies 1. Brno: Masaryk University, 2018, s. 89-95. O historických souvislostech revitalizace termínu bosenský jazyk viz HLADKÝ, L.: Bosenská otázka v 19. a 2o. století. Ediční řada Monografie. Svazek č. 12. Brno: Masarykova univerzita v Brně, Mezinárodní politologický ústav, 2005, S. 280-281.

20 Př.: V aktuálním daviscupovém zápasu Bosna a Hercegovina - Česko hrají Bosňané proti Čechům. Bosňané vyznávají tři různá náboženství: sunnitský islám (především Bosňáci), pravoslavné křestaanství (především Srbové) a římskokatolické křest̉anství (především Chorvati). 
však nutno odmítnout, výraz *Bosenec do českého jazyka nepřináší žádný chybějící sémantický rys, pouze působí ještě větší zmatky.

\section{VII.2 Bosenský vs. bosñácký}

Pro vyjádření vztahu k Bosně (ale i k státu Bosna a Hercegovina, není-li nezbytně nutné explicitně uvést dvoukomponentové adjektivum bosensko-hercegovský) nebo k obyvatelskému jménu Bosňan je jediným možným adjektivem (ktetikem) slovo bosenský, které je ekvivalentem orig. bosanski. Pro vyjádření vztahu k národnímu jménu Bosňák je jediným možným adjektivem slovo bosňácký, které je ekvivalentem orig. bošnjački. Jedinou výjimkou je tu pojmenování jazyka Bosňáků - jediným možným ekvivalentem orig. bosanski jezik je bosenský jazyk. Srbská ani chorvatská preferovaná podoba bošnjački jezik není v daném př́padě relevantní, český překlad by měl odrážet situaci v inkriminovaném národním jazyce, nikoliv situaci v jiných národních jazycích.

\section{VII.3 Federacija Bosne i Hercegovine}

Překlad pojmenování větší $\mathrm{z}$ entit $\mathrm{BaH}$ může $\mathrm{v}$ češtině odrážet přístup v originálním jazyce - tedy Federace Bosny a Hercegoviny, ve zkrácené podobě Federace BaH nebo jen Federace, je-li z kontextu zřejmé, o jakou územně-správní jednotku se jedná (podobně jako se v kontextu druhé světové války hovoří např. o Protektorátu). Z neoficiálních opisných pojmenování, která jsme výše uvedli, preferujeme podobu bosňácko-chorvatská federace, nebở ta asi nejlépe vyjadřuje to, čím tento subjekt skutečně v etnicko-politickém smyslu je.

\section{VII.4 Republika Srpska}

Překlad pojmenování menší z obou entit $\mathrm{BaH}$ je z hlediska míry ekvivalence největší problém - sice se v českém úzu ustálil a dodnes se použivá překlad Republika srbská, avšak tento svou podobou anomální název vychází z mylné představy, že orig. Srpska je adjektivum. ${ }^{21}$ Otázka ovšem je, jak jinak bychom př́slušný název mohli přeložit, když současná čeština jiné exonymum pro srbský stát, než je již obsazené Srbsko, nemá. Nabízí se ještě využití neinverzní podoby Srbská republika, avšak pouze v případě, že by se útvar zvaný srb. Република Србија důsledně překládal jen jako Republika Srbsko. Pak by se pro útvar zvaný srb. Република Српска mohla využít podoba Srbská

21 Tvar Srpska sice formálně je adjektivum, ale jelikož pojmenovává nějaký subjekt (území), je funkčně substantivem vzniklým slovnědruhovou konverzí. Tento postup tvoření geografických jmen je ostatně v srbochorvatštině běžný - viz Hrvatska, Bugarska, Češka, Slovačka, Poljska, Nemačka, Finska, Irska apod. 
republika. Další hypotetickou možností je substantivizace českého adjektiva srbská. $\mathrm{V}$ češtině existuje řada toponym, která jsou ženského rodu a mají adjektivní skloňování (např. Haná, Karviná, Orlová, Planá, exonymum Čenstochová aj.), a tuto řadu by mohl rozšírit i tvar Srbská, který by posloužil jako ekvivalent orig. Српска. V tuto chvíli se ale musíme smířit s tím, že geografické jméno Српска v češtině ekvivalent nemá a formální pojmenování Република Српска př̀kládáme inverzně a ne zcela v souladu se současnými zvyklostmi češtiny jako Republika srbská.

\section{Prameny:}

PSJČ 2007-2008 [1935-1937]: HUJER, O., SMETÁNKA, E., WEINGART, M., HAVRÁNEK, B., ŠMILAUER, V., ZÍSKAL, A. (red.): Př́ruční slovník jazyka českého. Díl I. A-f. Praha: Česká akademie věd a umění, Státní nakladatelství, 1935-1937. Digitalizované vydání: Ústav pro jazyk český, v.v.i., 2007-2008. [online]. [cit. 23. 10. 2019]. $<$ https://bara.ujc.cas.cz/psjc/>.

RBJ 2007: ČEDIĆ, I. (ur.): Rječnik bosanskog jezika. Sarajevo: Institut za jezik, 2007.

RHJ 200o: ŠONJE, J. (gl. ur.): Rječnik hrvatskoga jezika. Zagreb: Leksikografski zavod Miroslav Krleža, Školska knjiga, 2000.

RHSKJ 1967: Rječnik hrvatskosrpskoga književnog jezika, knjiga prva: A-F. Zagreb: Matica hrvatska, 1967.

RSHKJ 1967: Rečnik srpskohrvatskoga književnog jezika, knjiga prva: A-E. Novi Sad: Matica srpska, 1967.

RSHKJ 1969: Rečnik srpskohrvatskoga književnog jezika, knjiga treća: $K-O$ (kosjerić-ogranuti). Novi Sad: Matica srpska, 1969.

RSHKNJ 1962: Rečnik srpskohrvatskog književnog i narodnog jezika, knjiga II: bogoljub-vražogrnci. Beograd: SANU, 1962.

RSHKNJ 1988: Rečnik srpskohrvatskog književnog i narodnog jezika, knjiga XIII: Moire-naklapuša. Beograd: SANU, 1988.

RSJ 2007: Rečnik srpskoga jezika. Novi Sad: Matica srpska, 2007.

RSSKJ 2000 [1966]: MOSKOVLJEVIĆ, M.: Rečnik savremenog srpskog književnog jezika s jezičkim savetnikom. Beograd: Gutenbergov Alaksija, 200o. 〈1. izd. 1966〉

SJČ 1952 [1934-1937]: [VÁŠA, P. a] TRÁVNÍČEK, F.: Slovník jazyka českého. Čtvrté, přepracované a doplněné vydání. Praha: Slovanské nakladatelství, 1952. 〈1. vyd. 1934-1937.

SR 1852: STEFANOVIĆ KARADŽIĆ, V.: Srpski rječnik, istumačen njemačkijem i latinskijem riječima. Wien: U štampariji jermenskoga manastira, 1852. 〈2. izd.〉 [online]. [cit. 23. 10. 2019]. <http://digital.bms.rs/ebiblioteka/pageFlip/reader/index. php?type $=$ publications \&id $=1255 \& \mathrm{~m}=2 \#$ page $/ 1 /$ mode $/ 2 u p>$. 
SR 1966 [1818]: STEFANOVIĆ [KARADŽIĆ], V:: Srpski rječnik, istolkovan njemačkim

i latinskim riječma. Wien: P. P. Armeniern, 1818. 〈Vydáno jako Srpski rječnik (1818).

Sabrana dela Vuka Karadžića. Knjiga druga. Beograd: Prosveta, 1966.)

SSJČ 1989 [1960]: HAVRÁNEK, B. (hl. red.): Slovník spisovného jazyka českého. I a-g. Praha: Academia, 1989. 〈1. vyd. 1960. $\rangle$

SSČ 2000 [1978]: FILIPEC, J., DANEŠ, F. (hl. red.): Slovník spisovné češtiny pro školu a veřejnost. Praha: Academia, 200o. 〈1. vyd. 1978.

ŠRBJ 1999: JAHIĆ, Dž.: Trilogija o bosanskom jeziku, knjiga III. Školski rječnik bosanskog jezika. Sarajevo: Ljiljan, 1999.

VRHJ 2003: ANIĆ, V.: Veliki rječnik hrvatskoga jezika. Zagreb: Novi Liber, 2003.

\section{Literatura:}

HLADKÝ, L.: Bosenská otázka v 19. a 20. století. Ediční řada Monografie. Svazek č. 12. Brno: Masarykova univerzita v Brně, Mezinárodní politologický ústav, 2005. HLADKÝ, L.: Bosna a Hercegovina. Historie neštastné země. Brno: Doplněk, 1996. KLIMEŠ, L.: Slovník cizích slov. 5., prrepracované a doplněné vydání. Praha: SPN, 1994. KREJČÍ, P.: Eight Fragments from the World of Serbian, Croatian, Bosnian and Montenegrin Languages. Selected South Slavonic Studies 1. Brno: Masaryk University, 2018. KREJČÍ, P.: Lingvonyma v ústavách postjugoslávských státních útvarů (Chorvatsko, Bosna a Hercegovina, Srbsko a Černá Hora). In: BOGOCZOVÁ, I., NEDOMOVÁ, Z. (red.): Area Slavica 2. Slovanské jazyky ve světle termínu. Ostrava: Ostravská univerzita, 2018, s. 23-39.

MRDJEN, S.: Narodnost u popisima. Promjenljiva i nestalna kategorija. In: Stanovništvo, 1-4, 2002, s. 77-104.

\section{About the author}

\section{Pavel Krejčí}

Masaryk University, Faculty of Arts, Department of Slavonic Studies, Brno, Czechia pkrejci@phil.muni.cz

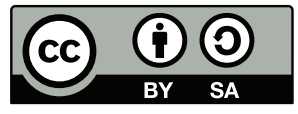

Toto dílo Ize užít v souladu s licenčními podmínkami Creative Commons BY-SA 4.0 International (<https:// creativecommons.org/licenses/by-sa/4.0/legalcode>). Uvedené se nevztahuje na díla či prvky (např. obrazovou či fotografickou dokumentaci), které jsou v díle užity na základě smluvní licence nebo výjimky či omezení přislušných práv. 